\title{
Atraumatiske skulderlidelser
}

\author{
Sammendrag \\ Bakgrunn. Skuldersmerter er den \\ tredje hyppigste årsaken til konsulta- \\ sjon for muskel- og skjelettsmerter \\ i primærhelsetjenesten. De fleste \\ pasientene har en atraumatisk skul- \\ derlidelse. I denne artikkelen diskute- \\ res utfordringer i diagnostikk og \\ behandling.
}

Materiale og metode. Artikkelen er basert på tidligere publiserte artikler, et ikke-systematisk litteratursøk i PubMed og søk i Cochrane Library.

Resultater. En enkelt klinisk test gir ikke grunnlag for å stille en patoanatomisk diagnose. Hyppigheten av degenerative forandringer i normalbefolkningen vanskeliggjør tolking av bildediagnostikk. MR er indisert på spesifikk indikasjon og er først og fremst en preoperativ undersøkelse. Ultralyd er like god for vurdering av rotatorcuffen. Kliniske studier viser ikke entydige effekter av spesifikk behandling. Dette kan skyldes metodiske svakheter, betydningen av prognostiske faktorer og betydelige placeboeffekter. Det er grunnlag for å anbefale injeksjon med glukokortikoider ved adhesiv kapsulitt. Ved subakromiale smerter har øvelser eller veiledet trening og operativ behandling sammenliknbar effekt, men det er ikke tilstrekkelig grunnlag for anbefalinger ved ruptur.

Fortolkning. Sykehistorien og en kombinasjon av kliniske tester samt konservativ behandling er vanligvis tilstrekkelig ved atraumatiske skulderlidelser. Ultralyd bør være førstevalg ved behov for bildediagnostikk.

\author{
Jens Ivar Brox \\ jens.ivar.brox@rikshospitalet.no \\ Ortopedisk avdeling \\ Oslo universitetssykehus, Rikshospitalet \\ 0027 Oslo \\ og \\ Det medisinske fakultet \\ Universitetet i Oslo

\section{Per Sunde} \\ Klinikk Frogner \\ Cecilie Piene Schrøder \\ Ortopedisk avdeling \\ Lovisenberg diakonale sykehus
}

\section{Kaia Engebretsen}

Avdeling for fysikalsk medisin og rehabilitering Oslo universitetssykehus, Ullevål

\section{Øystein Skare}

Ortopedisk avdeling

Lovisenberg diakonale sykehus

\section{Ole Marius Ekeberg}

Avdeling for fysikalsk medisin og rehabilitering Helse Fonna

\section{Niels Gunnar Juel}

Avdeling for fysikalsk medisin og rehabilitering Oslo universitetssykehus, Ullevål

Skuldersmerter forekommer hyppig. I løpet av et år har 46-47\% av befolkningen slike smerter over et kortere eller lengre tidsrom (1). De fleste oppsøker ikke lege eller annen behandler. Symptomer fra muskel og skjelett regnes som normalt. Prevalensen av skuldersmerter bør tolkes kritisk og ikke som et pålitelig uttrykk for sykdom i befolkningen. I en undersøkelse fant man at prevalensen av skulder- og ryggsmerter samt utbredte smerter var 2-4-doblet i England de siste 40 år (2). Lavere terskel for rapportering og økt oppmerksomhet om plagene ble fremhevet som mulige årsaker (2). Skuldersmerter er den tredje hyppigste årsaken til konsultasjoner for muskel- og skjelettplager i primærhelsetjenesten (3).

De fleste pasientene har en atraumatisk skulderlidelse, ofte rotatorcuffrelaterte plager. Begrepene impingementsyndrom og subakromiale smerter brukes også om slike plager. Ergonomiske og psykososiale arbeidsforhold kan ha betydning for symptomer og prognose. Det gjelder ensidig repeterende arbeid, vridninger og arbeid med verktøy og elevert arm, manglende kontroll over egen arbeidssituasjon og engstelse. Uspesifikke symptomer er vanlige, og ved langvarige plager bør psykososiale faktorer vurderes.

Lett tilgang til magnetisk resonanstomografi (MR) og operasjon kan bidra til at rota- torcuffrelaterte plager diagnostiseres for ofte. Tolking av bildediagnostiske avvik er vanskelig, fordi strukturelle endringer er vanlige også hos personer uten symptomer. Forekomsten av rupturer i rotatorcuffen øker med alder (4). Asymptomatisk ruptur ses for eksempel hos 15-25\% i aldersgruppen 70-79 år. De viktigste øvrige årsakene til ruptur er genetiske faktorer (5), traume, dominant arm og røyking (6). Innsatsstyrt finansiering og hyppig bruk av MR kan ha medvirket til at antall operasjoner for rotatorcuffrelaterte plager økte med $10 \%$ årlig i Sverige fra 1998-2004 (7), selv om man i randomiserte studier ikke fant effekt av operasjon (8).

\section{Materiale og metode}

Denne artikkelen bygger på et ikke-systematisk litteratursøk i PubMed og i Cochrane-databasen samt forfatternes egen forskning og kliniske erfaringer.

\section{Klassifisering}

Ved diagnostikk av ryggsmerter er det i dag anbefalt en tredelt klassifisering: spesifikke rygglidelser, uspesifikke rygglidelser og nerverotsmerter. En liknende inndeling er anbefalt vurdert for skulderdiagnostikk (9). Ikke-validerte kliniske tester og bildediagnostikk vektlegges for å gi pasienten en patoanatomisk diagnose for et problem som $\mathrm{i}$ mange tilfeller er sammensatt og der det finnes liten spesifikk effekt av behandling, inkludert operasjon. I figur 1 har vi skjematisk illustrert hvordan ulike skulderdiagnoser kan ha sammenfallende symptomer og funn.

De vanligste atraumatiske skulderlidelsene er uspesifikke skuldersmerter (myalgier), subakromiale smerter med eller uten degenerative rupturer, adhesiv kapsulitt og akro-

\section{Hovedbudskap}

- Skulderplager er tredje vanligste årsak til konsultasjon for muskel- og skjelettplager i allmennpraksis

- En kombinasjon av kliniske tester er nyttig ved de vanligste diagnosene

- Ukritisk bruk av bildediagnostikk kan forsterke upålitelig patoanatomisk klassifisering. Ultralyd og MR er likeverdig for å vurdere rotatorcuff

- Det er kunnskapsgrunnlag for at effekten av veiledet trening og operasjon ved subakromiale smerter er lik 
mioklavikulærleddsartrose. Eksempler på differensialdiagnoser er: glenohumeral artrose, inflammatorisk eller infeksiøs tenosynovitt eller artritt, leddleppeaffeksjon, bicepsseneaffeksjon, multidireksjonal instabilitet, nevritt, nerveskade pga. trykk (entrapment) (10), nerverotsmerter fra nakken, thoraxapertursyndrom, sympatisk refleksdystrofi eller skulder-hånd-syndrom og tumor. For en mer omfattende gjennomgang henvises for eksempel til skulderkapitlet $\mathrm{i}$ boken Norsk fysikalsk medisin (11).

\section{Sykehistorie}

Anamnesen skal være problemorientert og grundig, slik at den kan danne grunnlag for en målrettet og systematisk undersøkelse. Det er viktig å gi seg tid til å lytte til pasienten og ikke diktere sykehistorien under konsultasjonen. Konstante smerter som ikke forverres ved bevegelse av skulderen, kan ha forbindelse med andre organer (hjerte, galleblære). Pasienter med nakkesmerte har ofte ledsagende hodepine, kjevespenninger og skuldersmerte.

Subakromiale smerter er vanligvis lokalisert til lateralsiden av overarmen og forverres ved aktivitet med elevert arm, ved vridninger og repetert tungt arbeid. Symptombildet kan initialt likne adhesiv kapsulitt, men ved denne tilstanden ledsages etter hvert smerten av betydelig nedsatt bevegelighet, spesielt for utadrotasjon og abduksjon. Symptombildet ved uspesifikke skuldersmerter kan variere fra smerte lokalisert til en muskelgruppe til mer diffus smerte i skulder- og nakkeregionen. Noen pasienter rapporterer høyt emosjonelt stress og ledsagende somatiske symptomer som tegn på komorbiditet eller somatisering.

\section{Klinisk undersøkelse}

En god undersøkelse er viktig diagnostisk og kan bidra til å innfri pasientens forventninger. Undersøkelsen bør utføres avkledd til undertøyet på overkroppen. Observasjon av pasienten under avkledning kan gi nyttige opplysninger om funksjonsevnen. Videre kan skulderbladets posisjon og bevegelsesmønster, atrofi av muskulatur eller tumor vanskelig avdekkes dersom pasienten er påkledd. Det er nyttig å undersøke både affisert og ikke-affisert skulder. Undersøkeren făr et godt inntrykk av aktiv bevegelighet (abduksjon) ved å inspisere bakfra og å be pasienten heve armene samtidig ut til siden og opp mot taket. Det noteres når smerten begynner og forsvinner, dette beskrives som smertebue. Asymmetrisk bevegelse av skulderbladet betegnes som scapuladyskinesi eller endret humeroskapulær rytme. Bevegelsen kan forstyrres av torakal kyfose, aktiviteten i ulike deler av trapeziusmuskelen, interskapulærmusklene, brystmusklene og smerte. Scapuladyskinesi kan være et resultat av, eller bidra til, smerter i skulderbuens muskulatur og reduserte plassforhold subakromialt.

Dersom den aktive bevegeligheten er begrenset eller smertefull, bør videre undersø-

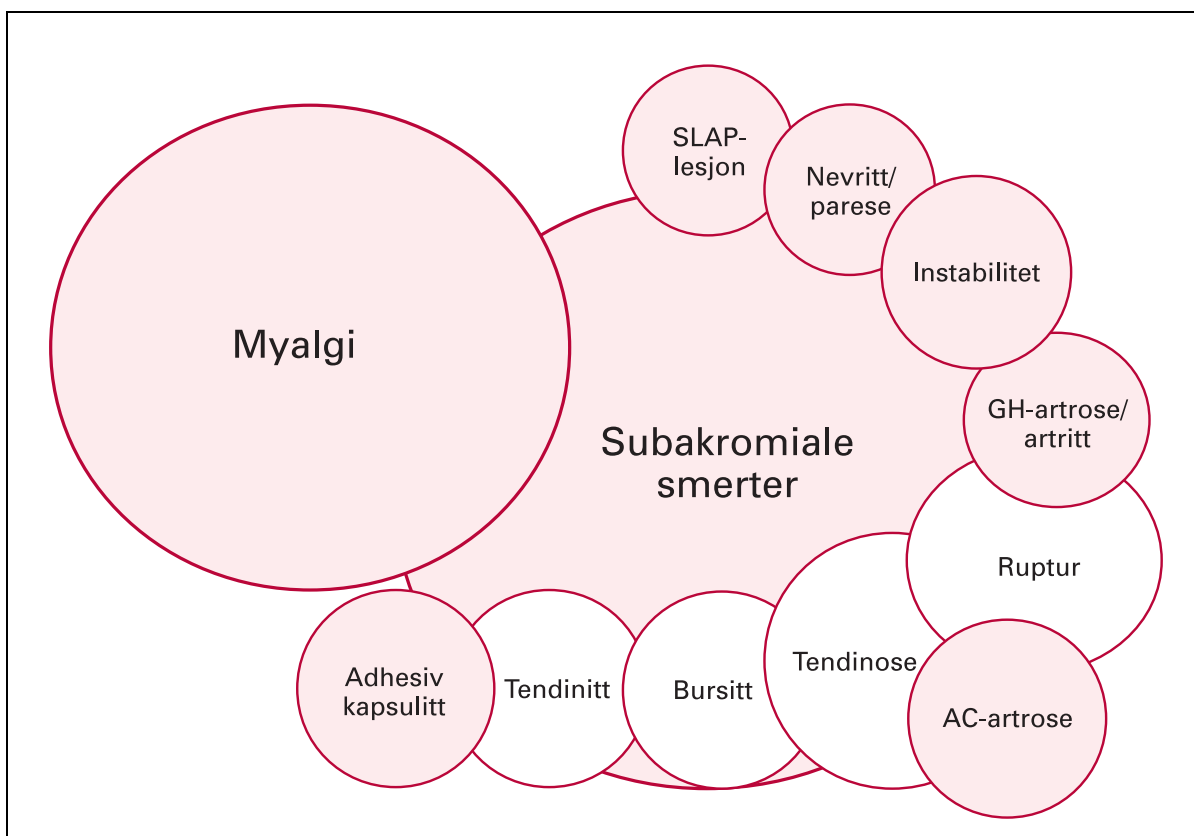

Figur 1 Skjematisk fremstilling for hvordan ulike tilstander i skulderen overlapper og kan gi subakromiale smerter (impingement). Adhesiv kapsulitt likner i tidlig fase, men karakteriseres av redusert leddbevegelighet. Glenohumeral artrose (GH-artrose) er en aktuell differensialdiagnose. Ultralyd er et godt hjelpemiddel for å skille inflammatorisk synovitt fra tenosynovitt. Ved affeksjon av akromioklavikulærleddet (AC-artrose) har pasientene smerter ved palpasjon og ved føring av armen over mot motsatt skulder. Særlig hos yngre pasienter kan affeksjon av leddleppen (SLAP) eller klinisk instabilitet uten at skulderen har luksert gi sekundære subakromiale smerter. Ultralyd og MR er likeverdige for å utelukke ruptur

kelser avdekke om dette skyldes leddstivhet, parese eller smerte. Den passive glenohumerale bevegeligheten bør undersøkes i utadrotasjon og abduksjon (kapsulært mønster), og dette kan gjøres som vist på figur 2. Bevegeligheten er alltid nedsatt ved adhesiv kapsulitt og kan være nedsatt ved artrose eller artritt.

Isometriske krafttester brukes til å avdekke kraftsvikt eller smerte (fig 2). Rupturer som går gjennom hele senetykkelsen affiserer hyppigst $\mathrm{m}$. supraspinatus, men også $\mathrm{m}$. infraspinatus og sjeldnere $\mathrm{m}$. subscapularis.

Inneklemmingstestene har som mål å utløse smerte ved å komprimere strukturene i det subakromiale rom (fig 2). Ved ledsagende nakkesmerter gjøres orienterende nevrologisk undersøkelse samt bevegelighetsundersøkelse av nakken. Redusert bevegelighet $\mathrm{i}$ albue $\mathrm{og}$ hånd kan påvirke skulderen $\mathrm{og}$ bør derfor undersøkes.

Det foreligger et bredt utvalg av kliniske tester for undersøkelse av skulderen (11). Nye oversiktsartikler konkluderer med at enkelttester har liten verdi (9). Det er knyttet metodiske problemer både til enkeltstudier og oversiktsartikler. Cyriax-metodikk har mange tilhengere $\mathrm{i}$ primærhelsetjenesten $\mathrm{i}$ Norge, og et modifisert Cyriax-klassifikasjonssystem legges til grunn for et utvalg av 13 tester anbefalt i boken Allmennmedisin (12). Metoden er erfaringsbasert og lite vitenskapelig utprøvd, men flere av enkelttestene er som vist i figur 2. Vanlige ortopediske tester for inneklemming (Neers test, Hawkins' test) eller styrketest for supraspi- natus (empty can test), motstandstester (lag signs) for senerupturer og O'Briens test for leddleppeaffeksjon, tilfredsstiller ikke metodiske kvalitetskrav for enkelttester (9).

En problemorientert sykehistorie bør suppleres med en målrettet klinisk undersøkelse inkludert en kombinasjon av tester. Atypiske funn eller langvarig forløp krever ny grundig gjennomgang av sykehistorien og ofte supplerende undersøkelser (13).

\section{Bildediagnostikk}

Implementering av ultralyd ved muskel- og skjelettlidelser går tregt i Norge. Mulige årsaker er overdreven respekt for lærekurven, manglende interesse hos radiologer og fravær av økonomiske incitamenter. Det utføres mye MR-diagnostikk ved utredning av kne, rygg og skulderlidelser. Ukritisk bruk kan føre til at pasienten gis en patoanatomisk diagnose som verken er årsak til symptomene eller riktig indikasjon for behandling (14).

I de fleste tilfeller er ultralyd tilstrekkelig, målrettet MR rekvireres på utvidede indikasjoner ved atypiske funn og preoperativt. For pasienter med atraumatiske skulderlidelser vil klinisk undersøkelse eventuelt supplert med dynamisk bilateral ultralyd vanligvis gi tilstrekkelig grunnlag for konklusjon. For vurdering av rotatorcuffen inkludert rupturer samt bicepssenen er MR og ultralyd likeverdige (15), men pasientene er mer fornøyd med ultralyd (16). Ultralyd er beste metode for å vurdere kalknedslag. Figur 3 viser ultra- 


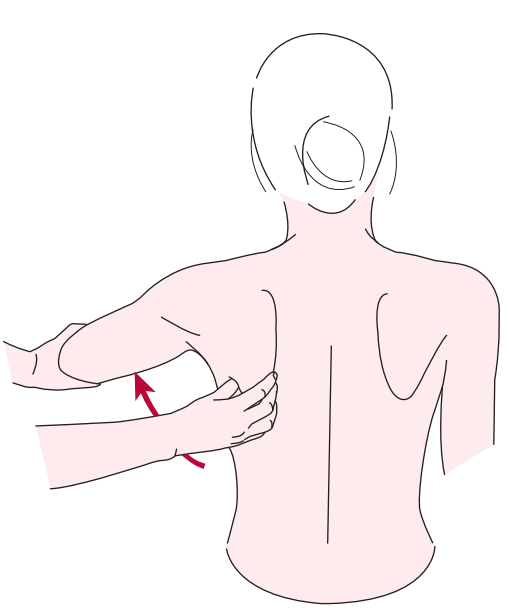

a

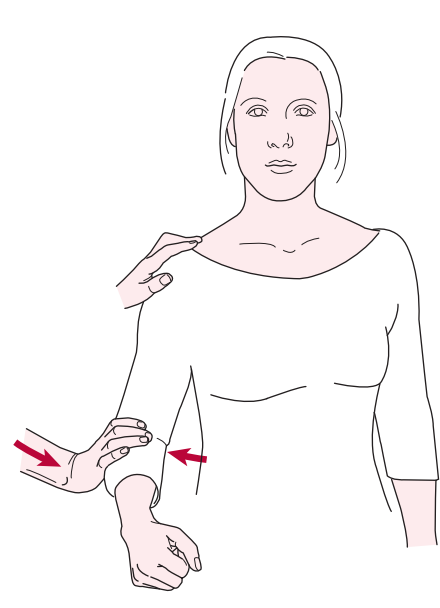

b

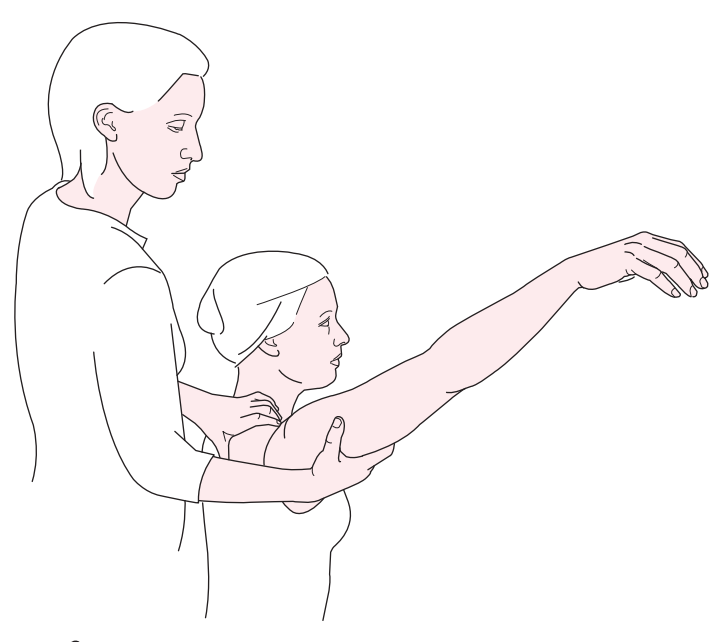

C

Figur 2 Klinisk undersøkelse av skulderen. a) Ved nedsatt aktiv bevegelighet undersøkes glenomhumeral bevegelighet.b) Isometrisk test av abduksjon og utadrotasjon. c) Det finnes flere tester for inneklemming av subakromiale strukturer. Felles er at undersøker flekterer og innadroterer for å komprimere og provosere smerte. Kraftsvikt ved b og positiv c tyder på ruptur, mens vesentlig smerteprovokasjon ved b og positiv c tyder på subakromiale smerter (tendinitt, bursitt eller tendinose). Supplerende kliniske tester beskrives i Norsk fysikalsk medisin (11)

lyd og MR ved supraspinatusruptur. For revmatologen er ultralyd et nyttig hjelpemiddel for å skille mellom synovitt og tenosynovitt. Radiologiske forandringer ses hos de fleste pasienter med revmatoid artritt få år etter sykdomsdebut. Synovial inflammasjon kan medføre bruskforandringer og forringe skulderfunksjonen. Skjelettrøntgen med «outlet view» (fig 4) er først og fremst indisert ved traumatiske skulderlidelser, men kan gi opplysninger om større påleiringer på undersiden av akromion, grad av glenohumeral artrose og om sjeldne tilstander, slik som nekrose av caput humeri. Artrose i akromioklavikulærleddet ses hyppig hos pasienter eldre enn 50 år, men er vanligvis ikke smertefullt.

\section{Behandling}

Behandlingens mål bør rettes mot pasientens hovedproblem. Pasienten ønsker en forklaring på hva plagene kan skyldes, en antydning om utsiktene til bedring og om behandling kan hjelpe. Metodene som anvendes kan gi spesifikk effekt og/eller placeboeffekt. Kunnskapsgrunnlaget omfatter mange studier, men metodiske svakheter med hensyn til bl.a. inklusjonskriterier, beskrivelse av intervensjonen, blinding, utvalgsstørrelse og utfallsmål, reduserer mulighetene til å gi klare anbefalinger. Det er likevel grunn til å vektlegge resultatene av randomiserte studier. Det foreligger få placebokontrollerte studier. Det er grunn til å anta at placebo utgjør en vesentlig del av effekten ved de vanligste behandlingsmetodene.

\section{Medikamenter og injeksjon}

Dersom pasienten opplever å bli hørt og undersøkt, kan enkle råd være tilstrekkelig behandling. Ikke-steroide antiinflammatoriske midler (NSAID-preparater) er vist å ha kortidseffekt ved skuldersmerter (17).
Ved adhesiv kapsulitt gir både peroral behandling og blind intrakapsulær/artikulær injeksjon av glukokortikosteroider smertelindring uten å forkorte varigheten av redusert bevegelighet (18). Distensjon av kapselen gir ikke bedre smertelindring eller bevegelighet (19). Pasienter med kapsulitt kan ha langvarige smerter og funksjonssvikt, men sluttresultatet er vanligvis godt.

Det har lenge vært spekulert i om injeksjon av glukokortikoider har effekt ved subakromiale smerter, særlig er langtidseffekten dårlig dokumentert $\mathrm{og}$ betydningen $\mathrm{av}$ injeksjonsmetodikk omdiskutert $(17,18)$. En ny norsk dobbeltblind undersøkelse tyder på at injeksjonens plassering ikke har avgjørende betydning (20).

\section{Fysioterapi}

Effekten av fysioterapi i form av øvelser, mobilisering, akupunktur, ultralyd, laser eller sjokkbølgebehandling er omdiskutert. Dette kan skyldes metodologiske svakheter eller intervensjonens kvalitet. En ny oversiktsartikkel konkluderer med at øvelser, even-

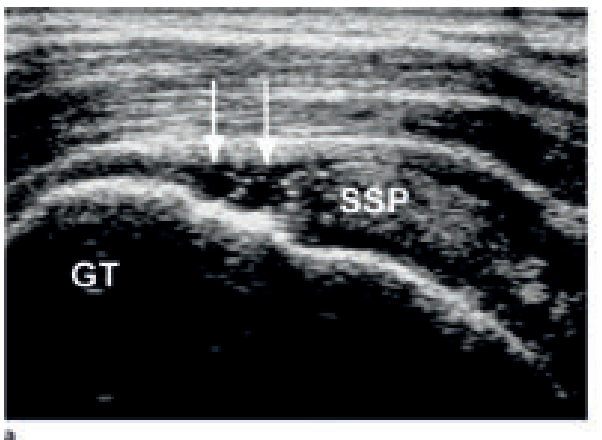

Figur 3 Gjennomgående (full tykkelse) ruptur av rotatorcuffen. a) Ultralyd viser gjennomgående ruptur (piler) ved festet av supraspinatussenen (SSP) på tuberculum majus (GT). b) MR-artrografi (skrått koronealt snitt) av rupturen (piler). Gjengitt med tillatelse fra Rutten og medarbeidere (15) tuelt supplert med mobilisering, har effekt (21). Øvelsesbehandling er ikke ensartet, noe som kan påvirke effekten (22). Vi fant at pasienter som hadde manglende effekt av injeksjon og fysioterapi i primærhelsetjenesten, hadde god og varig effekt av veiledet trening rettet mot å bedre funksjonen ved å normalisere muskelaktivering og bevegelsesmønster. Behandlingen omfattet bl.a. mobilisering, bruk av slynge og øvelser med mange repetisjoner og lav belastning veiledet av fysioterapeut i den første fasen (23). Effekten var like god som ved operasjon og bedre enn placebo. Behandlingen var ikke mer omfattende enn fysioterapi etter operasjon. I en nylig publisert studie fant vi at veiledet trening hadde bedre effekt enn sjokkbølgebehandling seks, 12 og 18 uker etter behandlingsstart (24).

I en ny Cochrane-rapport konkluderer man med at treningsterapi har like god effekt som operasjon ved subakromiale smerter (8). Det var ingen effekt på sykefravær og ingen kostnadsgevinst ved operasjon. Vi fant at bare halvparten av de sykmeldte hadde effekt av operasjon (25).

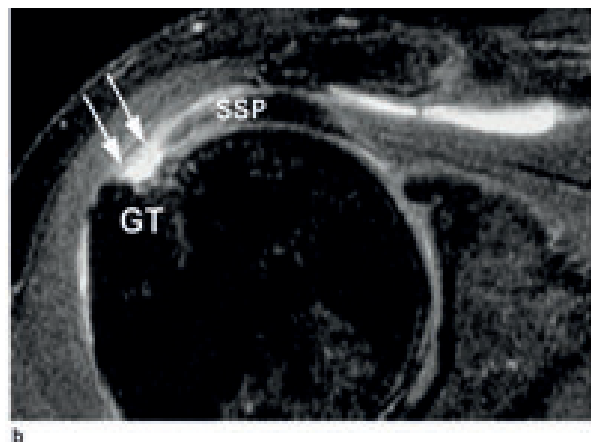




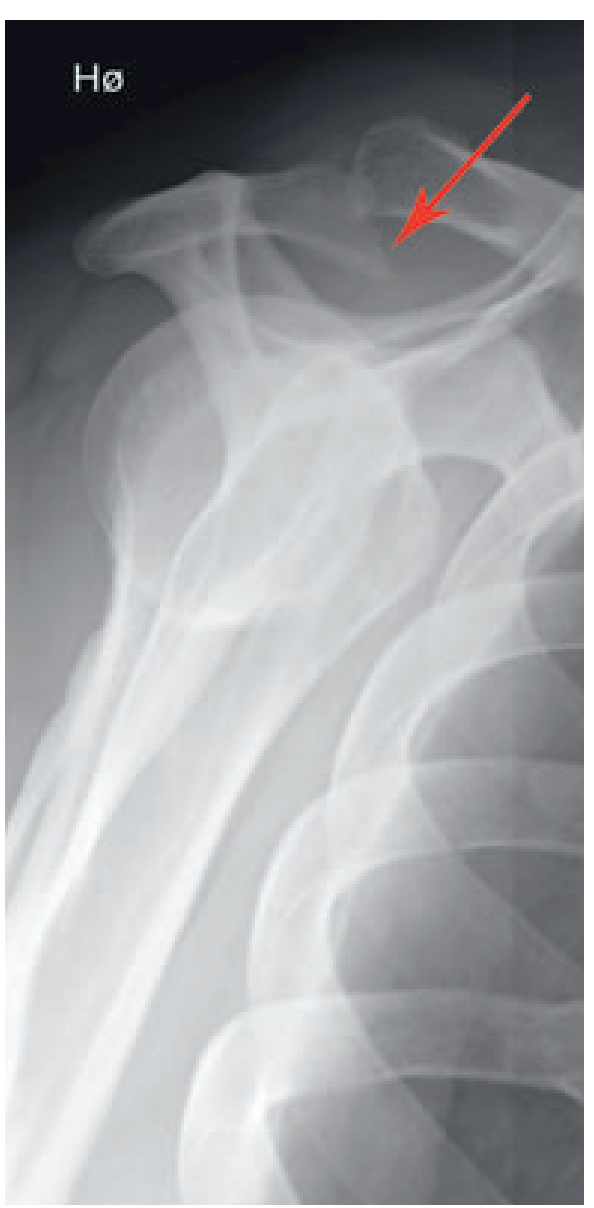

Figur 4 Skjelettrøntgen med «outlet view» viser uttalte degenerative påleiringer (pill) som reduserer plassforholdene i det subakromiale rom. Pasienten hadde kroniske subakromiale smerter uten vesentlig effekt av veiledet trening

\section{Kirurgi}

Det er vanskelig å forstå økningen i antall operasjoner på et kunnskapsmessig grunnlag. Pasientinformasjon om effekten av operasjon bør baseres på kunnskap fra randomiserte studier. Noen pasienter kan ha bedre effekt av operasjon. Det kan gjelde pasienter som enten er i fullt arbeid og ikke har hatt effekt av adekvat konservativ behandling eller har uttalte degenerative forandringer.

Det er mangelfullt kunnskapsgrunnlag for å fastslå om en ruptur er symptomgivende og om behandling hjelper (26). En eller flere av følgende faktorer kan tale for ikke-operativ behandling: at skulderen er ikke-dominant, at personen er sykmeldt, høy alder, atraumatisk, lite smerte og akseptabel funksjon, røyking, komorbiditet og store rupturer med degenerasjon av muskulatur (retraksjon og fettinfiltrasjon). Samtidig øker store rupturer risikoen for affeksjon av leddet (artropati) og dårlig funksjon. I en ny norsk randomisert studie fant man at prognosen var god både ved operasjon (akromionreseksjon og senesutur) og fysioterapi (veiledet trening utformet etter Mensendicks metodikk) (27), men operasjon var signifikant bedre. Resultatene av én enkelt studie er ikke tilstrekkelig for å gi retningslinjer, og mange spørsmål er fortsatt ubesvarte. Det er behov for studier som inkluderer simulering (sham) eller placebo og studier som sammenlikner akromionreseksjon med og uten senesutur.

Symptomatisk artrose i glenohumeralleddet forekommer relativt sjelden. Artrose kan skyldes genetiske faktorer, tidligere skader og andre sykdommer. Protese er aktuelt for pasienter med artritt eller artrose, betydelige plager og uttalte radiologiske forandringer. På bakgrunn av en systematisk oversiktsartikkel med 23 studier og 1952 pasienter anbefales totalprotese fremfor hemiprotese med utskiftning av caput humeri (28). Selv om mange av de inkluderte studiene er dårlige, var resultatene signifikant bedre for bevegelighet, pasientfornøydhet og revisjonskirurgi. Bedre standardiserte studier med lengre oppfølging er ønskelig.

\section{Konklusjon}

Skulderplager er den tredje vanligste årsak til at pasienter oppsøker allmennlege for muskel- og skjelettsmerter. Diagnosen stilles på grunnlag av sykehistorie og en kombinasjon av kliniske tester, eventuelt supplert med ultralyd. MR er indisert ved atypiske smerter og preoperativt. Kortisoninjeksjon er indisert for smertelindring ved adhesiv kapsulitt. Vi anbefaler veiledet trening ved subakromiale smerter. Anbefalingen støttes av nyere studier (29-31). Operasjon vurderes ved seneruptur for pasienter som ikke har effekt av adekvat konservativ behandling. Mange faktorer har betydning for prognosen. En god allmennlege bruker kunnskapsbasert medisin i undersøkelse og behandling, kartlegger pasienten og setter realistiske mål.

\section{Oppgitte interessekonflikter: Ingen}

\section{Litteratur}

1. Luime JJ, Koes BW, Hendriksen IJ et al. Prevalence and incidence of shoulder pain in the general population; a systematic review. Scand J Rheumatol 2004; 33: 73-81.

2. Harkness EF, Macfarlane GJ, Silman AJ et al. Is musculoskeletal pain more common now than 40 years ago?: Two population-based cross-sectional studies. Rheumatology (Oxford) 2005; 44: 890-5.

3. Urwin M, Symmons D, Allison T et al. Estimating the burden of musculoskeletal disorders in the community: the comparative prevalence of symptoms at different anatomical sites, and the relation to social deprivation. Ann Rheum Dis 1998; 57 649-55

4. Yamamoto A, Takagishi K, Osawa T et al. Prevalence and risk factors of a rotator cuff tear in the general population. J Shoulder Elbow Surg 2010; 19: $116-20$.

5. Gwilym SE, Watkins B, Cooper CD et al. Genetic influences in the progression of tears of the rotator cuff. J Bone Joint Surg Br 2009; 91: 915-7.

6. Baumgarten KM, Gerlach D, Galatz LM et al. Ciga rette smoking increases the risk for rotator cuff tears. Clin Orthop Relat Res 2010; 468: 1534-41.

7. Nordquist A, Rahme H, Hovelius L et al. Axelns sjukdomar. Läkartidningen 2007; 104: 1492-6.

8. Coghlan JA, Buchbinder R, Green S et al. Surgery for rotator cuff disease. Cochrane Database Syst Rev 2008; nr. 1: CD005619.

9. Hughes PC, Taylor NF, Green RA. Most clinical tests cannot accurately diagnose rotator cuff path ology: a systematic review. Aust J Physiother 2008; 54: $159-70$

10. Schrøder CP, Skare $\emptyset$. Stiris M et al. Treatment of labral tears with associated spinoglenoid cysts without cyst decompression. J Bone Joint Surg Am 2008; 90: 523-30

11. Juel NG, red. Norsk fysikalsk medisin. 2. utg. Ber gen: Fagbokforlaget, 2007

12. Hunskår S. Allmennmedisin. Oslo: Gyldendal Akademisk, 2003

13. Siebenrock KA, Hertel R, Ganz R. Unexpected resection of soft-tissue sarcoma. More mutilating surgery, higher local recurrence rates, and obscure prognosis as consequences of improper surgery. Arch Orthop Trauma Surg 2000; 120 : $65-9$

14. Englund M, Guermazi A, Gale D et al. Incidental meniscal findings on knee MRI in middle-aged and elderly persons. N Engl J Med 2008; 359: 1108-15.

15. Rutten MJ, Spaargaren GJ, van Loon T et al. Detection of rotator cuff tears: the value of MRI following ultrasound. Eur Radiol 2010; 20: 450-7.

16. Middleton WD, Payne WT, Teefey SA et al. Sonography and MRI of the shoulder: comparison of patient satisfaction. AJR Am J Roentgenol 2004 183: $1449-52$

17. Gaujoux-Viala C, Dougados M, Gossec L. Efficacy and safety of steroid injections for shoulder and elbow tendonitis: a meta-analysis of randomised controlled trials. Ann Rheum Dis 2009; 68: 1843-9.

18. Buchbinder R, Green S, Youd JM. Corticosteroid injections for shoulder pain. Cochrane Database Syst Rev 2003; nr. 1: CD004016.

19. Tveitå EK, Tariq R, Sesseng $S$ et al. Hydrodilatation, corticosteroids and adhesive capsulitis: a randomized controlled trial. BMC Musculoskelet Disord 2008; 9: 53.

20. Ekeberg OM, Bautz-Holter E, Tveitå EK et al. Subacromial ultrasound guided or systemic steroid injection for rotator cuff disease: randomised double blind study. BMJ 2009; 338: a3112.

21. Kuhn JE. Exercise in the treatment of rotator cuff impingement: a systematic review and a synthesized evidence-based rehabilitation protocol. J Shoulder Elbow Surg 2009; 18: 138-60.

22. Østerås H, Arild Torstensen T, Arntzen $\mathrm{G}$ et al. A comparison of work absence periods and the associated costs for two different modes of exercise therapies for patients with longstanding subacromial pain. J Media Econ 2008; 11: 371-81.

23. Brox JI, Staff PH, Ljunggren AE et al. Arthroscopic surgery compared with supervised exercises in patients with rotator cuff disease (stage II impingement syndrome). BMJ 1993; 307: 899-903

24. Engebretsen K, Grotle M, Bautz-Holter E et al. Radial extracorporeal shockwave treatment com pared with supervised exercises in patients with subacromial pain syndrome: single blind randomised study. BMJ 2009: 339 (sep 15 1): b3360.

25. Brox JI, Brevik JI. Prognostic factors in patients with rotator tendinosis (stage II impingement syndrome) of the shoulder. Scand J Prim Health Care $1996 ; 14: 100-5$.

26. Ejnisman B, Andreoli CV, Soares BG et al. Interventions for tears of the rotator cuff in adults. Cochrane Database Syst Rev 2004; nr. 1: CD002758

27. Moosmayer S, Lund G, Seljom U et al. Comparison between surgery and physiotherapy in the treatment of small and medium-sized tears of the rotator cuff: A randomised controlled study of 103 patients with one-year follow-up. J Bone Joint Surg Br 2010; 92: 83-91

28. Radnay CS, Setter KJ, Chambers L et al. Total shoulder replacement compared with humeral head replacement for the treatment of primary glenohumeral osteoarthritis: a systematic review. J Shoulder Elbow Surg 2007: 16: 396-402.

29. Ketola S, Lehtinen J, Arnala I et al. Does arthroscopic acromioplasty provide any additional value in the treatment of shoulder impingement syndrome? A two-year randomised controlled trial. J Bone Joint Surg Br 2009; 91: 1326-34.

30. Vitale MA, Arons RR, Hurwitz $S$ et al. The rising incidence of acromioplasty. J Bone Joint Surg Am 2010; 92: 1842-50.

31. Virta L, Mortensen M, Eriksson R et al. How many patients with subacromial impingement syndrome recover with physiotherapy? A follow-up study of a supervised excercise programme. Adv Physiother 2009; 11: 166-73.

Manuskriptet ble mottatt 9.9. 2009 og godkjent 3.6. 2010. Medisinsk redaktør Are Brean. 